\title{
Asian perspectives of migration: a commentary
}

\author{
Yuk Wah Chan
}

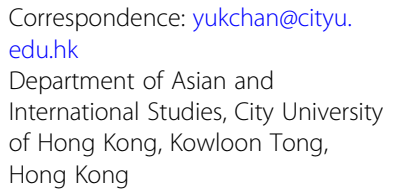

Correspondence: yukchan@cityu edu.hk

Department of Asian and International Studies, City University of Hong Kong, Kowloon Tong, Hong Kong

\begin{abstract}
This commentary discusses the scope of institutionalization by providing a regional dimension of migration studies. A pivotal weakness of the article is its lack of understanding of Asian migration scholarship which has thrived in the past two decades and has been a great impetus for the development of migration studies.
\end{abstract}

Keywords: Asian migration, Age of migration, Supermobility, Superdiversity

\section{The scope for institutionalization}

The paper has nicely summed up the different knowledge streams of the academic field of migration studies and their development in the past few decades. By using the term 'institutionalization', it leads us to think systemically about the knowledge production process, mechanism of the maintenance and continuation of this knowledge field. It also provides fascinating quantified data on relevant scholarly clusters, and it is quite clear that migration scholars have increasingly self-identified with such a field. There is also strong evidence for inter-referencing and the development of epistemic communities serving as platforms of debates. Perhaps one negligence is the lack of mention of the increasing numbers of programmes, centres, clusters, networks that pool resources for training migration researchers, e.g. postgraduate students, with special focuses on migration. This is one important factor to the expansion of migration studies and building up migration scholarly communities.

Yet, in order to better understand the scope of this institutionalization, I hope to bring attention back to the origin of knowledge production, i.e. the social phenomenon that gives rise to research and provides us with field data. Migration has become a 'global' scene since the turn of the century, and with the rise of 'the age of migration' (Castles and Miller 1993), scholars and researchers are paying much of the needed efforts to explore and understand such a phenomenon. We are seeing around 272 million of international migrants by 2019 (UNDESA 2019). Asia is the region producing the most international migrants and, like Europe, receiving the most (MDP 2020). The abundance of international migrations in Asia has given rise to Asian migration scholarship emerged since the mid-2000s. One major weakness of the paper is the lack of

(c) The Author(s). 2020 Open Access This article is licensed under a Creative Commons Attribution 4.0 International License, which permits use, sharing, adaptation, distribution and reproduction in any medium or format, as long as you give appropriate credit to the original author(s) and the source, provide a link to the Creative Commons licence, and indicate if changes were made. The images or other third party material in this article are included in the article's Creative Commons licence, unless indicated otherwise in a credit line to the material. If material is not included in the article's Creative Commons licence and your intended use is not permitted by statutory regulation or exceeds the permitted use, you will need to obtain permission directly from the copyright holder. To view a copy of this licence, visit http://creativecommons.org/licenses/by/4.0/. 
understanding of this scholarship, despite the fact that it has mentioned briefly how Asian scholarship on migration has been lacking behind in terms of co-authorship.

The prominence of Asian migration, both as an empirical phenomenon and as an academic turn of interest in Asian scholarship to migration studies, has been one pivotal factor for the expansion of migration studies. One may see Asian migration as a new stream in migration studies with a stress on a regional dimension. The rise of Asian migration has at least contributed to migration studies in 3 ways:

- Provide numerous empirical migration cases that are rich sources of knowledge production.

- Spark off research interest among younger scholars into the field; many of them are from Asian research and education institutes or/and are themselves migrants.

- Contribute intriguing cases for the further development of migration framework and theoretical refinement.

\section{Regionalization of migration studies}

Asian migration, the migration flows to and from Asia, has captured the attention of many Asian and western researchers. With the rise of the 'Asian century', the region has become the 'power house' generating migration mobility. If the 1990s was the age of migration (Castles and Miller 1993), the 2010s could be 'the age of Asian migration' (Chan et al. 2014; Chan et al. 2015). A large number of Asian and western scholars (across disciplines such as geography, anthropology, sociology, political studies, gender and development studies) have engaged in migration research in the region. Phd students in Asia have also shown great interest in the field. Asian migration scholarship has not only picked up cases and classified the variety of migration paths and forms, it has also conversed with global migration theories and engaged in theoretical framing and suggesting new sub-fields and key concepts.

\section{Cold war legacy}

The Cold Wars in Asia in the second half of the last century had produced large pools of displaced persons or refugee migrants (e.g. from Vietnam, Cambodia and Laos), who were resettled in different western countries or dispersed in Asian places. There has been an intrinsic connection between the Asian refugee diaspora and new Asian migrations after the 1990s. These earlier Asian diasporas continued to be an important pulling factor for chain migration from their home countries. The political standoffs during the Cold War period had also resulted in the government organized programmes of labour migration between communist Asia and communist Europe. Thus, the formation of the Asian diasporas in late last century has clearly manifested a split between government-related and anti-government migrant communities (Chan and Tran 2011).

\section{Gender and migration}

Economic disparity in Asia has made developed countries magnet for those opting for upward mobility and better-paid jobs. Low-skilled labour migration is one dominant feature in Asia, and this migration is often a gendered one. One special field that emerged from labour migration is 'migrant domestic helper studies' (Constable 1997; Parrenas 2000; 
Piper and Roces 2003; Lan 2006; Cheng 2006; Huang et al. 2005; Huang et al. 2012; Chan 2015; Piper and Withers 2017) which is particularly prominent among scholars and researchers concerning about development and human rights. A number of them also collaborated with international organizations, such as IOM and ILO. This migration field has put a re-emphasis on the development-migration and development-gender nexus.

Besides labour migration, another prominent form of gender related migration in Asia is 'marriage migration', which has resulted in the development of a global marriage market and boosted cross-border mobility (Wang and Hsiao 2009; Yang and Lu 2010). This form of migration has witnessed hundreds of thousands of Asian brides crossing border to join the newly met husband in affluent Asian places, such as Japan, South Korea, Singapore, Taiwan and Hong Kong. Vietnam, for example, is a major source country for such migration. The demand for more subservient wives in the receiving countries and the desire for upward mobility in the sending countries have given rise to a global marriage market controlled, manipulated, and shaped by many 'introduction marriage' agencies, which in turn augment the momentum for overseas marriage (Wang and Chang 2002). Some have also argued for the structural affinity faced by low-skilled foreign domestic helper migrants and foreign wives (Piper and Roces 2003; Lauser 2008). Both of these migration fields are dominated by female migrants and have contributed to the 'feminization of migration'.

\section{Nouveau rich Asian migrants}

Unlike what happened in the 19th and twentieth century, Asians today do not migrate as 'poor migrants'; there are numerous nouveau rich Asian migrants. The flourishing of the Asian economy since the beginning of the new millennium has made migration affordable for many. Affluent Asian migrants settled elsewhere through investment and education. China, for examples, has sent over three million scholars and students abroad since 1978 (Liu and van Dongen 2016). Chinese student migrants in the early years may not be considered as rich. Yet, increasingly, many overseas Chinese students were observed as conspicuously rich. Overall, Asians are the top source of investment as well as education migration in and beyond Asia. China is now producing a large number of HNWI (high net wealth individuals) who are also investment migrants. HNWI from PRC not only used their newly gained wealth to attain overseas citizenship, they also deployed their capitals to get access to various strategic investment opportunities around the world. Migration (through whatever forms and means) is no longer merely a 'migration', but family strategies for investment and transferal of capitals (Chan 2018). The dichotomy between the assimilation and transnationalism model may limit one's understanding of the new dynamics and political economy in migration.

\section{Asian diasporas}

Vis-a-vis the kind of 'superdiversity' in the west (Vertovec 2007), sporadic political economies in Asia have led to a kind of 'supermobility' in Asia. Migrants actually conduct periodic returns to home for better economic opportunities - such as job and business. Many Asians quickly recycle their migration turns and conduct multiple and circular migrations (sometimes within only a few years) (Ley and Kobayashi 2005; Tsuda 2003; Xiang et al. 2013). This 'supermobility' is made possible by the particular 
political and economic realities in Asia and the multifarious migration schemes drafted by various governments in and beyond Asia.

Asian diasporas, formed at different times, under different political economic contexts and from different places of origin, have made researchers tap the question 'what is a diaspora'. Diaspora, often prefixed with an ethno label, may not be an adequate term to cover all those within a certain ethnic group or from a certain country. Some have explored dissonant diasporas (King and Christou 2011; Chan 2013). Different migration experiences and continued transiency have complicated the formation and split within overseas migrant communities.

\section{Migration governance and the state}

The new challenge for migration studies is how migration governance has affected state power and state-migrant relationship. How has migration mobility challenged state power and re-shaped the role of the state? How do governments continue their governance over overseas subjects (both permanent and temporary migrants)? How has migration mobility challenged the notion of the 'national community' (Chan 2019)? Many migrant-sending countries have implemented diaspora-engagement initiatives A relevant concept, 'emigration state', has been coined by Gamlen (2008). China and Vietnam, for example, are particularly active in engaging overseas national communities. How do these measures affect migrants who dwell beyond national borders? How would overseas subjects affect the politics of the mother countries? How would this diaspora-state interaction affect international relations? Do sovereign powers stop at national borders? All these questions pose new dilemmas for political scientists.

\section{Conclusion}

All in all, Asian migration has provided an important impetus for grounding migration studies into various academic debates and infusing the field with much needed research passion and energy. Empirically, Asia has brought about a large spectrum of migration stories which entail various migration paths (South-North, North-North, South-South and North-South), providing fertile ground for migration research. The 2000s and 2010s witnessed the emergence of active migration scholars from Asia, including those from Singapore, Hong Kong, South Korea, Japan, the Philippines, Taiwan and China, who helped to expand international readership on migration work. Many migration scholars and researchers are themselves migrants, and have attended to migration which they have first-person experiences. Asian migrations also offer rich field data and cases for testing theoretical concepts which in turn help framing issues. Thus, to bring to light the issues of growing scholarly interest in migration studies, one should not have neglected the great impetus that Asian migration scholarship has had on the institutionalization of migration as a research field.

Author's contributions

The author read and approved the final manuscript. 
Received: 1 May 2020 Accepted: 1 May 2020

Published online: 02 October 2020

\section{References}

Castles, S., \& Miller, M. (1993). The age of migration: International Population Movements in the Modern World. New York: The Guilford Press.

Chan, Y. W. (2013). Hybrid diaspora and identity-laundering: A study of the return overseas Chinese Vietnamese in Vietnam. Asian Ethnicity, 14(4), 525-541.

Chan, Y. W. (2015). Asian women and Asian migration: A review and prospective research agenda. In Y. W. Chan, H. Fung, \& G. Szymańska-Matusiewicz (Eds.), The Age of Asian Migration: Continuity, Diversity, and Susceptibility (vol. 2, pp. 18-41). Newcastle: Cambridge Scholars Publishing.

Chan, Y. W. (2018). New directions for overseas Chinese and migration studies. In Y. W. Chan, \& S. Y. Koh (Eds.), New Chinese Migrations: Mobility, Home, and Inspirations (pp. 211-221). London: Routledge.

Chan, Y. W. (2019). Asian migrations and the evolving notions of national community. In S. Gold, \& S. Nawyn (Eds.), Routledge international handbook of migration studies (pp. 416-430). London: Routledge.

Chan, Y. W., Fung, H., \& Szymańska-Matusiewicz, G. (2015). The Age of Asian Migration: Continuity, Diversity, and Susceptibility, (vol. 2). Newcastle: Cambridge Scholars Publishing.

Chan, Y. W., Haines, D., \& Lee, J. (Eds.) (2014). The age of Asian migration: Continuity, diversity, and susceptibility (vol. 1). Newcastle: Cambridge Scholars Publishing.

Chan, Y. W., \& Tran, T. L. T. (2011). Recycling migration and changing nationalisms: Vietnamese return diaspora and reconstruction of the Vietnamese nationhood. Journal of Ethnic and Migration Studies, 37(7), 1101-1117.

Cheng, S.-J. A. (2006). Serving the household and the nation: Filipina domestics and the politics of identity in Taiwan. Lanham: Lexington Books.

Constable, N. (1997). Maid to order in Hong Kong: Stories of Filipina Workers. Ithaca: Cornell University Press.

Gamlen, A. (2008). The emigration state and the modern geopolitical imagination. Political Geography, 27, 840-856.

Huang, S., Thang, L. L., \& Toyota, M. (2012). Transnational mobilities for care: Rethinking the dynamics of care in Asia. Global Network, 12(2), 129-134.

Huang, S., Yeoh, B. S. A., \& Rahman, N. A. (2005). Asian women as transnational domestic workers. Singapore: Marshall Cavendish Academic.

King, R., \& Christou, A. (2011). Of counter-diaspora and reverse transnationalism: Return mobilities to and from the ancestral homeland. Mobilities, 6(4), 451-466.

Lan, P.-C. (2006). Global Cinderellas: Migrant domestics and newly rich employers in Taiwan. Durham: Duke University Press.

Lauser, A. (2008). Philippine women on the move: Marriage across Borders. International Migration, 46(4), 85-110.

Ley, D., \& Kobayashi, A. (2005). Back to Hong Kong: Return migration or transnational sojourn? Global Networks, 5(2), 111-127.

Liu, H., \& van Dongen, E. (2016). China's diaspora policies as a new mode of transnational governance. Journal of Contemporary China, 25, 805-821.

MDP (Migration Data Portal). (2020). https://migrationdataportal.org/themes/international-migrant-stocks\%E2\%80\%A8. Accessed 19 Dec 2019.

Parrenas, R. S. (2000). Migrant Filipina domestic workers and the international division of reproductive labor. Gender and Society, 14(4), 560-580.

Piper, N., \& Roces, M. (Eds.) (2003). Wife or worker? Asian women and migration. Lanham: Rowman \& Littlefield.

Piper, N., \& Withers, M. (2017). Migrant Precarity in Asia: 'Networks of labour activism' for a rights-based governance of migration. Development and Change, 48(5), 1089-1110.

Tsuda, T. (2003). Strangers in the ethnic homeland: Japanese Brasilian return migration in transnational perspective. New York: Columbia University Press.

UNDESA (2019). International Migration 2019 Report. New York: The United Nations.

Vertovec, S. (2007). Superdiversity and its implications. Ethnic and Racial Studies, 30(6), 1024-1054.

Wang, H. Z., \& Chang, S. M. (2002). The commodification of international marriages: Cross-border marriage business in Taiwan and Vietnam. International Migration, 40(6), 93-116.

Wang, H. Z., \& Hsiao, H. M. (Eds.) (2009). Cross-border marriages with Asian characteristics. Taipei: Academia Sinica, Center for Asian Pacific Area Studies.

Xiang, B., Yeoh, B., \& Toyota, M. (Eds.) (2013). Return: Nationalizing transnational mobility in Asia. Durham: Duke University Press.

Yang, W. S., \& Lu, M. (2010). Asian cross-border marriage migration: Demographic patterns and social issues. Amsterdam: Amsterdam University Press.

\section{Publisher's Note}

Springer Nature remains neutral with regard to jurisdictional claims in published maps and institutional affiliations. 